\title{
ELECTRO-SYNTHETIC OPTIMIZATION OF HOST MATERIAL BASED ON MIL-100(Fe)
}

\section{OPTIMASI SINTESIS HOST MATERIAL BERBASIS MIL-100(Fe) SECARA ELEKTROKIMIA}

\author{
Witri Wahyu Lestari ${ }^{1,2 *}$, Joni Hartono ${ }^{1}$, Marisa Adreane ${ }^{1}$, \\ Khoirina Dwi Nugrahaningtyas ${ }^{2}$, Candra Purnawan ${ }^{3}$, Sentot Budi Rahardjo' \\ ${ }^{1}$ Inorganic and organo-metallic complexes research group, Chemistry Department, Faculty \\ of Mathematics and Natural Sciences, Sebelas Maret University, Surakarta, Indonesia \\ ${ }^{2}$ Research Group of Porous Material for Sustainability, Chemistry Department, Sebelas \\ Maret University, Surakarta, Indonesia \\ ${ }^{3}$ Analytical and Environmental Chemistry Research Group, Chemistry Department, \\ Faculty of Mathematics and Natural Sciences, Sebelas Maret University, Surakarta, \\ Indonesia \\ *email: witri@mipa.uns.ac.id
}

Received 9 February 2016; Accepted 12 April 2016; Available online 16 May 2016

\begin{abstract}
Electro-synthesis of Metal-Organic Frameworks types of MIL-100(Fe) (MIL = Material Institute of Lavoisier) in ethanol: water (1: 1) with electrolyte TBATFB $0.1 \mathrm{M}$ has been optimized by varying voltage $(12,13,14$ and 15 Volt) and temperature (room temperature, 40, 60 and $80{ }^{\circ} \mathrm{C}$ ). The product showed light brown powder which upon activation becomes dark brown. Optimum condition achieved during use voltage of 15 Volts and at a temperature of $40{ }^{\circ} \mathrm{C}$ with $33 \%$ yield. The obtained material was characterized by XRD and compared to CCDC 640536 simulated patterns to confirm the phase purity of the product. As comparison hydrothermal and reflux method have been carried out. Characterization by FTIR has also undertaken to ensure the coordination between the metal cation $\left(\mathrm{Fe}^{3+}\right.$ ) and the BTC ligand (BTC $=1,3,5$-Benzene Tri Carboxylate). Meanwhile pore analysis using SAA confirmed that MIL-100(Fe) obtained by electrolysis method has a BET surface area reached till $569.191 \mathrm{~m}^{2} / \mathrm{g}$ with a total pore volume of $0.4540 \mathrm{cc} / \mathrm{g}$ and an average pore diameter reached $16 \AA$. Based on SEM analysis, morphology material show particle size between 0.4-8.6 $\mu \mathrm{m}$ and has a thermal stability up to $350{ }^{\circ} \mathrm{C}$ according thermo-gravimetric analysis. Due to the presence of Lewis acid sites on Fe-trimeric unit, porosity features on MIL- $100(\mathrm{Fe})$ and a fairly high thermal stability, this material is potentially used as the host material for the catalyst in the conversion reactions model for green diesel production.
\end{abstract}

Keywords: catalyst, electro-synthesis, green diesel, host material, MIL-100(Fe)

\begin{abstract}
ABSTRAK
Telah dilakukan optimasi sintesis Metal-Organic Frameworks jenis MIL-100(Fe) (MIL= Material Institute of Lavoisier) dengan metode elektrokimia dalam pelarut etanol:air (1:1) dan elektrolit TBATFB $0.1 \mathrm{M}$ dengan variasi tegangan (12, 13, 14 dan 15 Volt) dan variasi suhu (RT, 40, 60 dan $80^{\circ} \mathrm{C}$ ). Hasil sintesis menunjukkan serbuk kristallin berwarna coklat muda yang setelah aktivasi menjadi coklat tua. Hasil optimal didapatkan saat digunakan tegangan 15 Volt dan pada suhu $40{ }^{\circ} \mathrm{C}$ dengan yield (hasil sintesis) mencapai $33 \%$. Material hasil sintesis dikarakterisasi dengan XRD yang menunjukkan kesesuaian dengan
\end{abstract}


simulated pattern dari MIL-100(Fe)(CCDC 640536) yang mengindikasikan kemurnian fasa produk yang terbentuk. Sebagai pembanding dilakukan juga sintesis MIL-100(Fe) secara hidrotermal dan refluks. Karakterisasi dengan FTIR juga dilakukan untuk memastikan telah berkoordinasinya kation logam $\mathrm{Fe}^{3+}$ dengan ligan BTC $(\mathrm{BTC}=1,3,5$-Benzene Tri Carboxylate). Sementara itu analisis pori dengan SAA menunjukkan bahwa MIL-100(Fe) yang disintesis secara elektrokimia pada kondisi optimum memiliki luas permukaan BET mencapai $569,191 \mathrm{~m}^{2} / \mathrm{g}$ dan total volume pori mencapai $0,4540 \mathrm{cc} / \mathrm{g}$ dan rata-rata diameter pori mencapai $16 \AA$. Berdasarkan analisis SEM, morfologi material hasil sintesis memiliki ukuran antara $0,4-8,6 \mu \mathrm{m}$ dan memiliki stabilitas termal hingga $350{ }^{\circ} \mathrm{C}$ sesuai analisis termogravimetri. Mengingat adanya situs asam Lewis pada unit Fe-trimer, fitur porositas pada MIL-100(Fe) dan kestabilan yang cukup tinggi, ke depannya material ini potensial digunakan sebagai host material katalis untuk reaksi konversi green diesel.

Kata kunci: elektro-sintesis, green diesel, host material, MIL-100(Fe), katalis

\section{INTRODUCTION}

Nowadays, the major source of energy comes from fossil fuels, such as petroleum and coal. These kinds of fuels are not renewable and gradually decreasing. Moreover, the production of $\mathrm{CO}_{2}$ and $\mathrm{SO}_{2}$ as gaseous emissions has an adverse effect on the environment. Therefore, new alternative renewable and environmentally friendly fuels are urgently needed, as consequences the dependence to the fossil fuel can be reduced (He \& Wang, 2013). Owing rich in natural resources, renewable energy based on bio fuels are potentially developed in Indonesia, for instance is biodiesel (Yusuf, Kamarudin, \& Yaakub, 2011).

Biodiesel is present as one of the bio-fuel products, however, the use of conventional biodiesel (first generation of biodiesel) still remain some limitations. The carbon-carbon double bond $(\mathrm{C}=\mathrm{C})$ and carbon-oxygen $(\mathrm{C}=\mathrm{O})$ yielded on the trans-esterification products tend to have a high flash point (ignition) and sensitive to oxidation reaction (Sotelo-Boyás, et al., 2012). As an innovation, green diesel which is free of oxygen and the double bond is a promising solution.

Green diesel has a very similar structure to petro-diesel, but has some superior properties compared to petrodiesel and conventional biodiesel, among others, the cetane numbers close to 100 , and the cloud point below minus $30^{\circ} \mathrm{C}$, higher stability, free of aromatic compounds and sulfur, produce emissions far below ultra-free sulfur petro-diesel (Sotelo-Boyás, Trejo-Zárraga, \& Hernández-Loyo, 2012; Mäki-Arvela et al., 2012). The reaction's principle of green diesel production is going through hydrogenation and hydro-deoxygenation of triglycerides and fatty acids from plants, such as coconut palm, jatropha and microalgae (He \& Wang, 2013). Other than raw materials, another important factor determines the success of a green diesel production is the present of properly high activity and selectivity catalysts. Several studies concerning metal-based catalysts have been developed, for example based on $\mathrm{Pd}, \mathrm{Pt}$, and $\mathrm{Ru}$ metals. Those metals despite having high activity but still have low selectivity and very expensive. As a result, the distribution of cracking and decarboxylation results still dominates the product compared to the targeted products of hydrogenation/hydrodeoxygenation pathway (Yang, Ochoa-Hernandez, de la Peňa O 'Shea, Coronado, \& Serrano et al., 2012).

In this regard, one possible effort can be pursued in the development as well as catalysts innovation by utilizing metalorganic frameworks (MOFs) as a multifunctional host catalytic material. MOFs are crystalline porous materials with nanometer-scale, high purity and possess 
similar topology like zeolites. Mostly MOFs can be designed with considerable variation through design of the linker (organic ligands that have lone pair electrons at both ends, in the form of bidentate or polydentate ligand) and coordinated with several choices of metal in order to obtain a stronger coordination bond (Yang et al., 2010). In addition, due to the presence of stable pores and relatively high surface area, and the presence of Lewis acid sites, thus MOFs is very promising as one of a host catalyst to optimize the conversion of biofuels. One type of catalytic MOFs is $\left[\mathrm{Fe}_{3} \mathrm{OF}_{0.81}\right.$ $\left.(\mathrm{OH})_{0: 19}\left(\mathrm{H}_{2} \mathrm{O}\right)_{2}(\mathrm{BTC})_{2}\right]$ is referred to MIL-100(Fe) (Horcajada et al., 2007). MIL-100(Fe) is built up from carboxylate moieties (benzene-1,3,5-tricarboxylate (BTC)) and iron trimeric octahedral clusters which have removable terminal ligands $\left(\mathrm{H}_{2} \mathrm{O}, \mathrm{F}\right.$, or $\left.\mathrm{OH}\right)$ and therefore provide potential unsaturated metal sites for strong interaction (Horcajada et al., 2007). MOF-100(Fe) also has two types of large accessible and permanent pores (25 $\AA$ and $29 \AA$ in diameter) with micro porous windows $(5.5 \AA$ and $8.6 \AA$ in diameter) (Figure 1).

These compound showed high catalytic activity and selectivity on the Friedel-crafts benzylation reaction (Horcajada et al., 2007), meinwald rearrangement reactions (Dhakshinamoorthy, Opanasenko, Čejka, \& Garcia, 2013), styrene hydrogenation reaction (Dhakshinamoorthy, Alvaro, \& Garcia, 2012) and isomerization of endo to exo dicyclopentadiene (Kim, Kim, \& Cho et al., 2016).

Modifications Pd-metal nanoparticle onto MOFs through encapsulation process can increase the activity and selectivity of the catalyst, such as Pd@MOF-5 is used for the hydrogenation reaction of ethylcinnamate (Opelt et al., 2008) and hydrogenation at styrene (Sabo, Henschel, Frode, Klemm, \& Kaskel, 2007), Pd@MIL-101(Cr) for hydrogenation reactions of styrene and acetylene
(Henschel, Gredich, Kraehnert, \& Kaskel, 2008), hydrogenation of phenol (Liu, Li, Luque, \& Jiang, 2011) as well as the reduction of aryl alkyl ketones (Hermannsdörfer \& Kempe, 2011) and so on. Based on previous studies, then the future will be investigated encapsulation of Pd nano-particle on MIL-100(Fe) for the hydrogenation and hydrodeoxygenation reaction one of the simplest model compounds in vegetable oil components and tested the activity and selectivity. This is because the combination of $\mathrm{Fe}-\mathrm{Pd}$ expected to have better activity and selectivity.
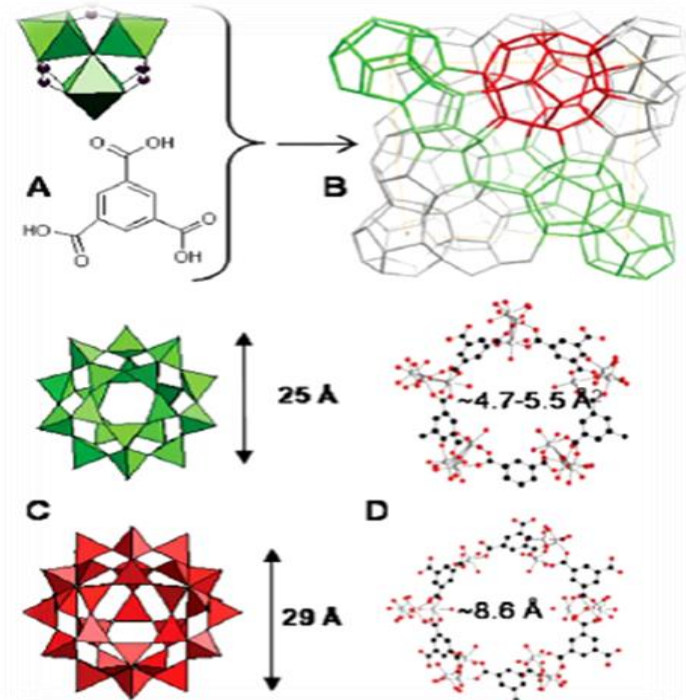

D

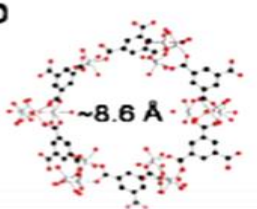

Figure 1. Structure of MIL-100 (Fe ${ }^{3+}$ BTC), where A. A trimeric unit Fe-octahedral and ligand BTC, B. overview schematic of the unit cell MIL-100(Fe), C. Two forms pores in the model polyhedral, D . Channel shaped pentagonal and hexagonal (Fe = gray, $\mathrm{O}=$ red, and $\mathrm{C}=$ black) (Horcajada et al., 2007).

Herein, as a preliminary study, the innovative electro-synthesis of host material, namely, MIL-100(Fe) will be presented. The synthetic innovation method in this regards is very important, because the previous method in synthesizing of these materials are usually using the hydrothermal method with a high temperature $\left(150{ }^{\circ} \mathrm{C}\right)$ by using a quite corrosive acid modulator (like $\mathrm{HF}$ 
and $\mathrm{HNO}_{3}$ ) lead to an exothermic reaction and takes a long reaction time. The employment of iron as a node in the MOFs because it is easy to find out, cheap and environmentally friendly (Jahangiri, Bennett, Mahjoubi, Wilson, \& Gua, 2014), as well as more selective in the hydrogenation and hydrodeoxygenation reaction through reverse Mars-Van Krevelen reaction mechanism (Kandel, Anderegg, Nelson, Chaudhary, \& Slowing, 2014).

\section{EXPERIMENTAL}

\section{Materials and Instruments}

All reagent has high purity with analytical reagent grade and used as purchased. Fe-plates with $99.9 \%$ purity are used as electrode material. 1, 3, 5benzene tricarboxylic acid (BTC) and tetrabutyl-ammonium-tetrafluoroborate (TBATFB) were purchased from ABCR, Germany and used without further purification. Analytical grade, ethanol was used as received from Merck. Before used, the electrode was activated by immersing in $100 \mathrm{~mL} \mathrm{HNO}_{3}(1 \mathrm{M})$ and scrub with sand-paper until shinny.

Electrosynthesis were conducted using electrochemical cell connected with regulated DC (Power Supply) ATTEN TPR 3005T-3C. Hydrothermal syntheses were carried out in steel autoclaves with appropriate teflon vessel. The temperature programs were applied in an oven UN30 (MEMMERT).

\section{Synthetic Procedure of MIL-100(Fe)}

Electrosynthesis of MIL-100(Fe) have been conducted according to modified synthetic procedure reported by Kumar, Kumar, and Kulandainathan (2013) by using modified solvent combination in water:ethanol $(1: 1)$ and tetra-butyl ammonium tetra-fluoroborate (TBATFB) $0.1 \mathrm{M}$ as electrolyte. Two Fe electrode having similar area $\left(10 \mathrm{~cm}^{2}\right)$ used as the source of the metal were placed in the vessel containing BTC ligand $(0,1 \mathrm{M})$ and electrolyte $(0,1 \mathrm{M})$ which have been dissolved in $50 \mathrm{~mL}$ solvent (etanol:water/1:1). Electrolysis was carried out in an electrochemical cell under constant voltage electrolysis (with keeping current varying to make voltage constant) for ca. $2 \mathrm{~h}$ to complete the reaction. The electrochemical cell has also been connected to reflux system in order to conduct the temperature variation (40, 60 and $80{ }^{\circ} \mathrm{C}$ ). The voltages have also been varied ranging from 12-15 Volts. The brown color precipitate of MIL$100(\mathrm{Fe})$ was collected from the electrolysis cell, filtered and washed with ethanol and allowed to dry at room temperature and then activated at $200{ }^{\circ} \mathrm{C}$ for $2 \mathrm{~h}$. As comparison, MIL-100(Fe) have also been synthesized under hydrothermal condition (at temperature condition $150{ }^{\circ} \mathrm{C}$ for 6 days and using $\mathrm{HF}$ and $\mathrm{HNO}_{3}$ as modulator) and under reflux at $95{ }^{\circ} \mathrm{C}$ for 12 hours without addition of $\mathrm{HF}$ according to the literature procedure (Zhang et al., 2015).

\section{Characterization}

The synthesized product was characterized by Powder X-Ray diffraction (Philips PW3040/60) using $\mathrm{Cu}-\mathrm{K} \alpha$ radiation $(\lambda=1.5406 \AA)$, with the voltage and current were held at $40 \mathrm{kV}$ and $30 \mathrm{~mA}\left(2 \theta=5-50^{\circ}\right)$ at a scan rate of $1 \%$ min. SEM data of samples were collected using SEM (FEI inspect S50) to confirm surface morphology. Fourier Transform Infrared spectrum has been recorded on a SHIMADZU FT-IRprestige 21 using $\mathrm{KBr}$ pellet in the range of $400-4000 \mathrm{~cm}^{-1}$.

The surface area and pore volume of the MIL-100(Fe) determined from BET adsorption isotherms of nitrogen at $77 \mathrm{~K}$ using a static volumetric apparatus Micrometrics, NOVA 1200e. Thermogravimetric analysis was performed using a STA Linseis pt 1600 instrument and experiments were conducted with a constant heating rate of $10{ }^{\circ} \mathrm{C} / \mathrm{min}$ under nitrogen atmosphere. 


\section{RESULTS AND DISCUSSION}

MIL-100(Fe) with molecular formula $\left[\mathrm{Fe}_{3} \mathrm{OF}_{0.81}(\mathrm{OH})_{0.19}\left(\mathrm{H}_{2} \mathrm{O}\right)_{2}(\mathrm{BTC})_{2}\right]$ is a kind of MOFs which intensively studied due to its thermal stability, high porosity, interesting chemical properties and prospective to be applied in catalysis (Horcajada et al., 2007; Dhakshinamoorthy et al., 2013; Dhakshinamoorthy et al., 2012; Kim et al., 2016) and biomedical application (Cunha et al., 2013). This material was firstly synthesized by Horcajada et al (2007) through hydrothermal condition under high temperature for 6 days in the presence of $\mathrm{HF}$ and $\mathrm{HNO}_{3}$ as modulator. The involvement of acids during hydrothermal reaction lead to an exothermic effect and can cause explosion. Moreover, the hydrothermal method needs longer reaction time, therefore a secure, efficient and environmentally friendly innovation synthetic method is required. In addition, the easy-handling and fast scaling up factor in the synthesis of material plays very crucial role in industrial scale. Due to those all reasons, we have focused to optimize synthesis MIL-100(Fe) through electrochemical method by varying several parameters, such as temperature and voltage. The yields of each variations are listed in Table 1. Synthesis under hydrothermal and reflux condition have also been tried as comparison.

Table 1. The yield of MIL-100(Fe) synthesized by electrochemical method (with voltage and temperature variations) compared to hydrothermal and reflux method

\begin{tabular}{cccc}
\hline No & $\begin{array}{c}\text { Temperature } \\
\left({ }^{\circ} \mathbf{C}\right)\end{array}$ & Voltage $(\mathbf{V})$ & $\begin{array}{c}\text { Yield } \\
(\%)\end{array}$ \\
\hline 1 & RT & 15 & 13.56 \\
2 & 40 & 15 & 32.72 \\
3 & 60 & 12 & 27.97 \\
4 & 80 & 12 & 20.23 \\
5 & 40 & 13 & 21.17 \\
6 & 40 & 14 & 12.83 \\
7 & 90 & reflux & 37.79 \\
8 & 150 & hydrothermal & 40.29 \\
\hline
\end{tabular}

The product showed light brown powder which upon activation becomes dark brown and have been characterized using PXRD to confirm the phase purity by comparing to simulated pattern (CCDC 640536) (Horcajada et al., 2007). The diffractogram of the obtained materials are depicted in Figure 2 dan 3.

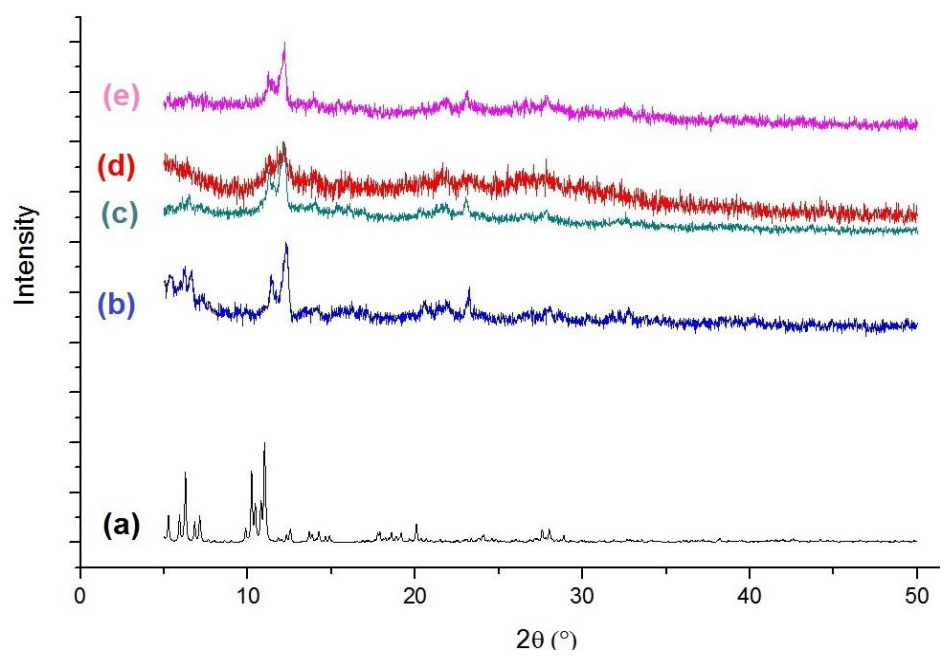

Fiugure 2. XRD-diffractogram of synthesized material from the electrochemical method at 15 Volt; RT (d), $80{ }^{\circ} \mathrm{C}$ (e), $60{ }^{\circ} \mathrm{C}$ (c) and $40{ }^{\circ} \mathrm{C}$ (b) in comparison with simulated pattern from the single X-Ray data of MIL-100(Fe)(a) 


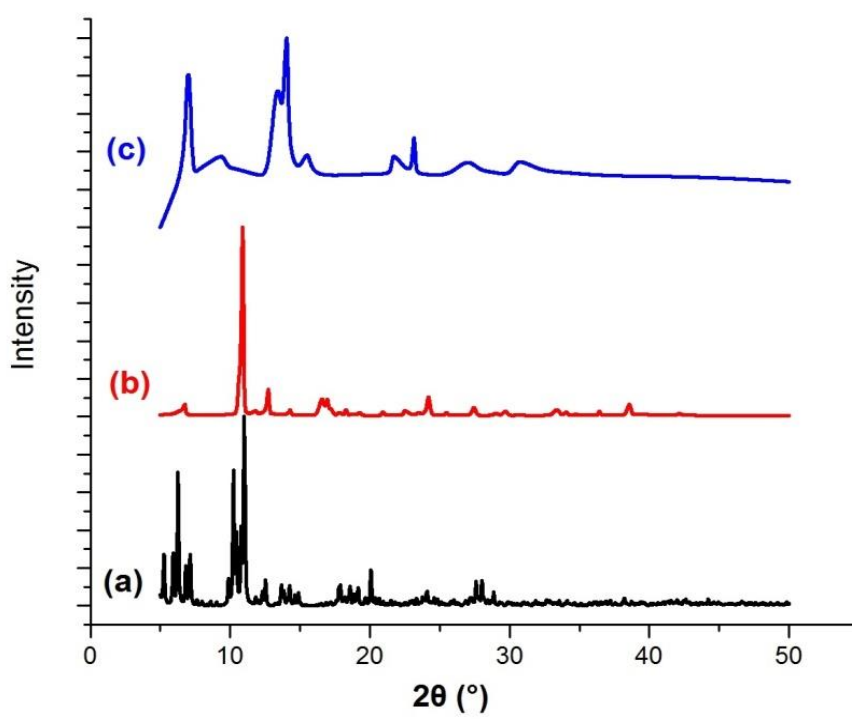

Figure 3. XRD-diffractogram of synthesized material through hydrotermal (b) and reflux (c) compared to simulated pattern (a)

According to Figure $\mathbf{2}$ and $\mathbf{3}$, it shown that in general the diffractogram of synthesized materials are in agreement with the simulated powder pattern from single crystal data of MIL-100(Fe) with the main $2 \theta$ on $20.1 ; 10.9 ; 10.03 ; 7.11$; 6.25 ; and 5.28, however the product from the electrochemical and reflux method have lower crystallinity than the hydrothermal product by using $\mathrm{HF}$ and $\mathrm{HNO}_{3}$ as modulator. The optimum condition for electrochemical method selected at 15 Volt and $40{ }^{\circ} \mathrm{C}$ based on the highest yield (ca.33\%) and the degree of crystallinity. As supporting data to ensure the formation of MIL-100(Fe), the FTIR analysis have been done. The significant changes of stretching vibration from $\mathrm{C}=\mathrm{O}$ acid ligand from $1715 \mathrm{~cm}^{-1}$ (free ligand) to $1665 \mathrm{~cm}^{-1}$ indicating that $\mathrm{C}=\mathrm{O}$ carboxyl from BTC have been deprotonated then coordinated with $\mathrm{Fe}^{3+}$ to form MIL$100(\mathrm{Fe})$. Besides that, the vibration characteristics of $422 \mathrm{~cm}^{-1}$ may be assigned as $\mathrm{Fe}-\mathrm{O}$ stretching vibration in which the oxygen atom coordinated with $\mathrm{Fe}^{3+}$. Broad peak at 2500-3300 $\mathrm{cm}^{-1}$ correspond to $\mathrm{OH}$ stretching absorption of carboxyl group and shifted from 3100 to
3600 at MIL-100(Fe), which indicates the presence of water molecules bond at iron trimeric unit on MIL-100(Fe).

FTIR spectra of pure ligand BTC and synthesized MIL-100(Fe) via hydrothermal or by electrolysis can be seen in Figure 4. Furthermore, stretching vibration of $-\mathrm{OH}$ indicates the presence of hydrogen bonding after coordinated with $\mathrm{Fe}^{3+}$. Thermal analysis confirms that MIL$100(\mathrm{Fe})$ is thermally stable until $350{ }^{\circ} \mathrm{C}$ and shows three steps of decomposition from temperature $25{ }^{\circ} \mathrm{C}$ till $400{ }^{\circ} \mathrm{C}$ (Figure 5). First decomposition (ca. $15.3 \%$ ) at 80 to $100{ }^{\circ} \mathrm{C}$ is attributed to the removal of the free ethanol and water molecules inside the pores. The second decomposition at $250{ }^{\circ} \mathrm{C}$ (ca.4.5\%) comes from the water molecules which coordinated with the iron trimers. The final weight loss (ca. 34.6\%) at $350{ }^{\circ} \mathrm{C}$ is related to the combustion of the trimesic acid. These latter two losses are, on the whole, in agreement with the theoretical values (calc: 4.6 and 35.2\%). The variable of water content on the structure of MIL$100(\mathrm{Fe})$ is considerably depending on the atmospheric condition (Horcajada et al., 2007). 


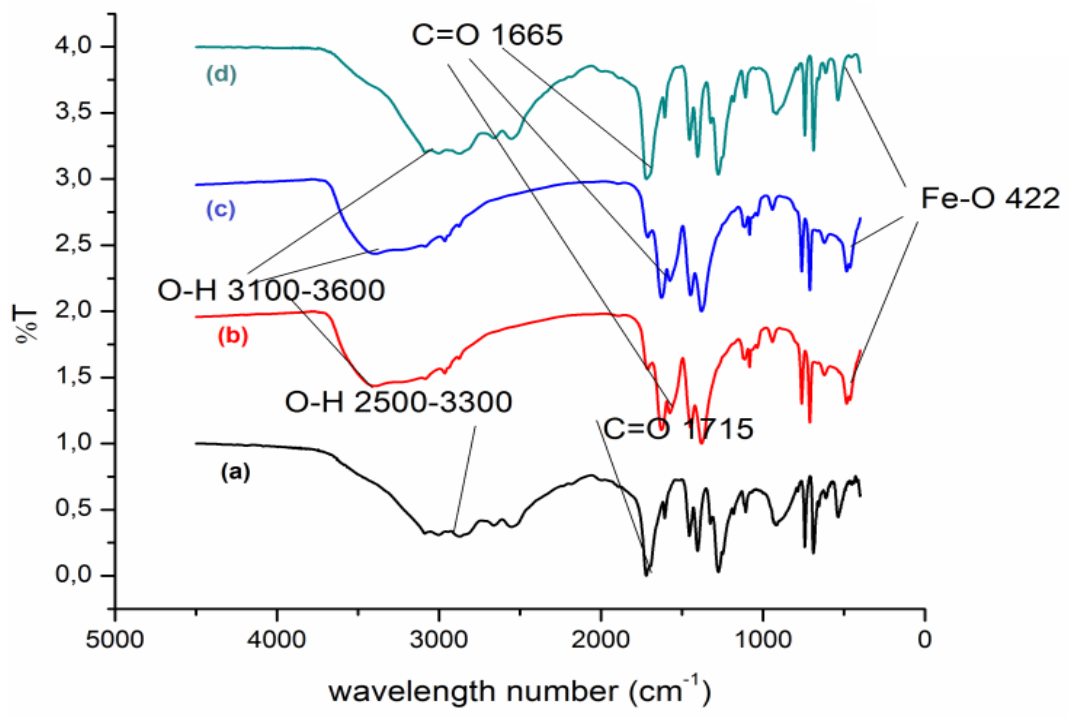

Figure 4. FT-IR spectra of (a) ligand: 1,3,5-benzene tricarboxylic acid and MIL-100(Fe) which electrochemically synthesized (after and before activation, $\mathbf{b}$ dan $\mathbf{c}$ ) and hydrothermal (d)

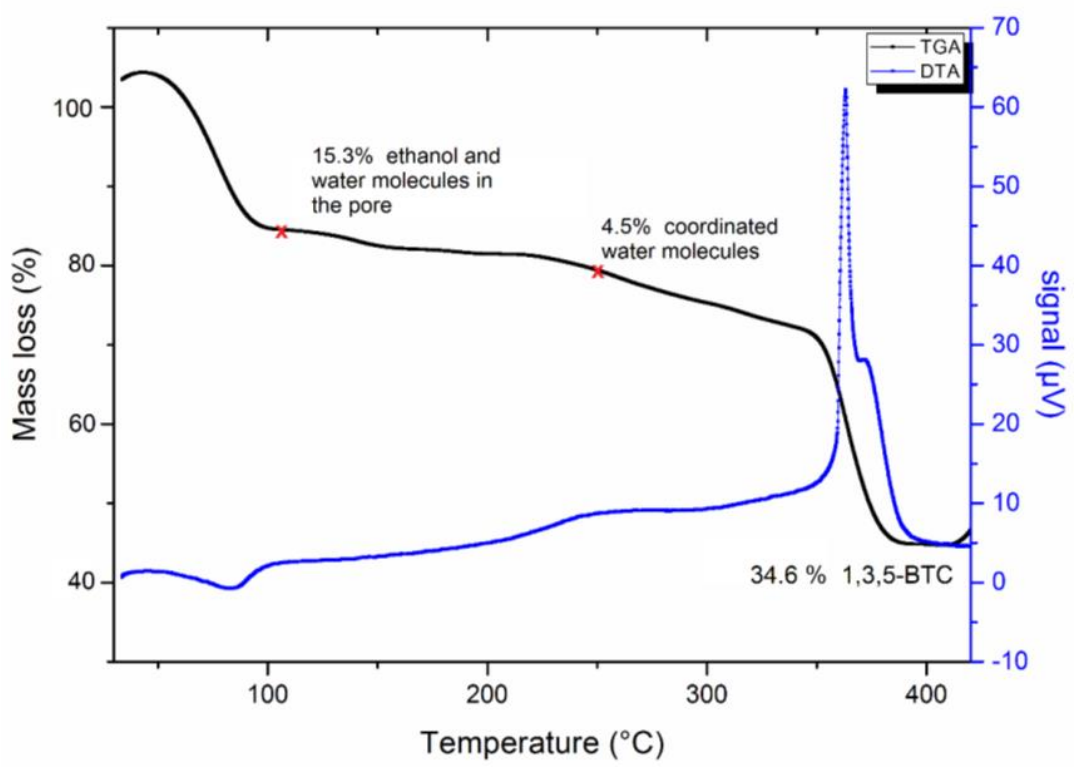

Figure 5. TG/DTA (thermo gravimetry analysis) of electro-synthesized MIL-100(Fe)

In order to proof that MIL-100(Fe) is a kind of MOF material with high porosity and promising as host catalytic material, surface area and porosity analysis (SAA) were performed. According to SAA analysis, the electrochemically synthesized MIL$100(\mathrm{Fe})$ (at optimum condition $15 \mathrm{~V}, 40$ ${ }^{\circ} \mathrm{C}$ ) has BET surface area of $569.191 \mathrm{~m}^{2} / \mathrm{g}$ with total pore volume of $0.4540 \mathrm{cc} / \mathrm{g}$ and a pore diameter average size of $16 \AA$. Based on size of the pore and the shape of nitrogen adsorption-desorption isotherm (Figure 6) it shows the type I of the nitrogen adsorption isotherms which typical for MOFs and can be categorized as micro-porous material according to IUPAC Recommendations (1985). 


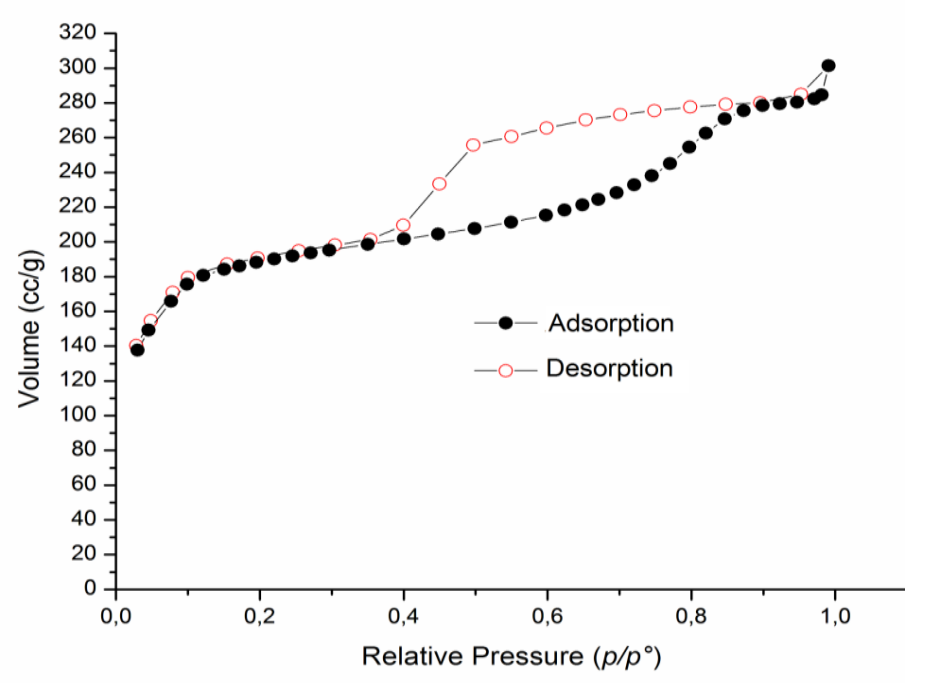

Figure 6. Nitrogen adsorption isotherm of the electro-synthesized MIL-100(Fe) after activation upon $200{ }^{\circ} \mathrm{C}$.

(a)

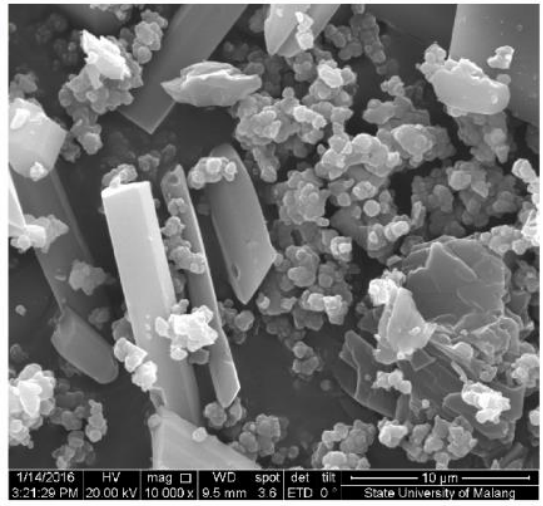

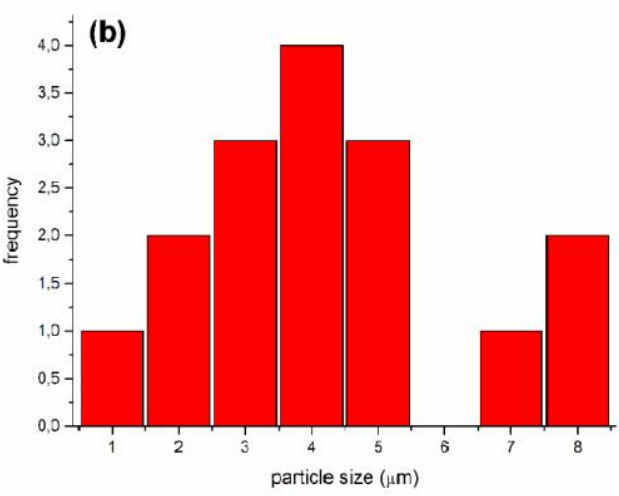

Figure 7. SEM Image of electro synthesized MIL-100(Fe) obtained $15 \mathrm{~V}, 40{ }^{\circ} \mathrm{C}$ with magnification $10.000 \times$ (a) particle size distribution of obtained MIL-100(Fe) in the range of $0,4-8.6 \mu \mathrm{m}$ (b)

Morphology analysis of MIL$100(\mathrm{Fe})$ using scanning electron microscopy (SEM) confirmed the powder has particle size distribution in the range of $0.4-8.6 \mu \mathrm{m}$ which is far smaller than MIL-100(Fe) synthesized from hydrothermal condition reported by Horcajada et al.(2007) (Figure 7).

From all the result indicates that electrochemical method can be as one alternative method in the synthesizing organometallic compound, especially MOFs. The synthesis is quite simple and fast, safe in handling and can be operated at lower temperature. Therefore, this method is suitable to produce large scale of MOFs material which applied to industrial scale due to time and cost efficient and environmentally friendly synthesis. In addition, the obtained material has lower degree of crystallinity compared to the product obtained from hydrothermal method which close to the nanoparticle size. Another advantage is possible to control the reaction every time to time and open new route for kinetic study in the near future.

\section{CONCLUSIONS}

Metal-Organic Frameworks (MOFs) types of MIL-100(Fe) has been successfully synthesized electrochemically. The optimum condition is found when the reaction carried out in ethanol:water (1:1) at a voltage of $15 \mathrm{~V}$ and a temperature of $40{ }^{\circ} \mathrm{C}$. The success of using electrolysis method gives new 
hope for the synthesis of organometallic material in a more secure, short-time, good quality material and fast scaling up processes that can be applied in the industry in the future. Due to some distinctive properties of MIL-100(Fe), such as porosity, thermal stability and the presence of Lewis acid sites make this material promising as a host catalytic material that later will be encapsulated with palladium $\left(\mathrm{Pd}^{\circ}\right)$ to form bimetalic catalyst and will be tested in hydrogenation and hydrodeoxygenation reaction on model compounds for green diesel production.

\section{ACKNOWLEDGEMENT}

The authors gratefully acknowledge financial support provided by KEMENRISTEK-DIKTI through ISINAS-RISTEK 2015 in the scope of fundamental research and MRG-Grant from PNBP UNS Surakarta.

\section{REFERENCES}

Cunha D., Yahia M. B., Hall S., Miller S. R., Chevreau H, Elkaïm E., Maurin G., Horcajada P., \& Serre C. 2013. Rationale of drug encapsulation and release from biocompatible porous metal-organic frameworks. Chemistry of Materials, 25 (14), 2767-2776. http://pubs.acs.org/doi/ abs/10.1021/cm400798p

Dhakshinamoorthy, A., Opanasenko, M., Čejka, J., \& Garcia, H. (2013). Metal-organic frameworks as heterogeneous catalysts for the production of fine chemicals. Catalysis Scince \& Technology, 3, 2509-2540. doi: 10.1039/C3CY00350G.http://pu bs.rsc.org/en/content/articlelanding/ 2013/cy/c3cy00350g\#!divAbstract

Dhakshinamoorthy, A., Alvaro, M., \& Garcia, H. (2012). Commercial metal-organic frameworks as heterogeneous catalysts. Chemical Communications, 48, 11275-11288. doi: 10.1039/C2CC34329K. http://p ubs.rsc.org/en/Content/ArticleLandi ng/2012/CC/C2CC34329K\#!divAbs tract

He, Z.,\& Wang, X. (2013). Hydrodeoxygenation of model compounds and catalytic systems for pyrolysis bio-oils upgrading. Catalysis for Sustainable Energy, 1, 28-52 doi: 10.2478/cse-2012-0004

Henschel, A. , Gedrich, K., Kraehnert, R., \& Kaskel, S. (2008).Catalytic properties of MIL-101.Chemical Communications, 4192-4194. doi: 10.1039/B718371B

Hermannsdörfer, J., \& Kempe, R. (2011). Selective palladium-loaded MIL101 catalysts. Chemistry European Journal, 17(29), 8071-8077. http://dx.doi.org/10.1002/chem.2011 01004

Horcajada, P., Surblé, S., Serre, C., Hong, D-. Y., Seo, Y.-K, Chang, J.-S., Grenéche, J.-M., Margiolakid, \& I. Férey, G. (2007). Synthesis and catalytic properties of MIL-100(Fe), an iron(III) carboxylate with large pores. Chemical Communications, 2820-2822. doi: 10.1039/B704325B

IUPAC Recommendations. (1985). Reproting physisoprtion data for gas/solid systems with special reference to the determination of surface area and porosity. Pure Appl. Chem. 57 (4), 603-619. http://pac.iupac.org/publications/pac /pdf/1985/pdf/5704x0603.pdf

Jahangiri, H., Bennett, J., Mahjoubi, P. , Wilson, K., \& Gua, S. (2014). A review of advanced catalyst development for Fischer-Tropsch synthesis of hydrocarbons from biomass derived syn-gas. Catalysis Science \& Technology, 4, 22102229. doi: 10.1039/C4CY00327F

Kandel, K., Anderegg, J. W., Nelson, N. C. Chaudhary, U., \& Slowing, I. I. (2014). Supported iron nanoparticles for the hydrodeoxygenation of microalgal oil to green diesel. 
Journal of Catalysis, 314, 142-148. doi:10.1016/j.jcat.2014.04.009

Kim, D.-W, Kim, H.-G, \& Cho, D.-H. (2016), Catalytic performance of MIL-100 (Fe, Cr) and MIL-101 (Fe, $\mathrm{Cr}$ ) in the isomerization of endo- to exo-dicyclopentadiene. Catalysis Communications, 73, 69-73. doi:10.1016/j.catcom.2015.10.006

Kumar, R. S., Kumar, S. S., \& Kulandainathan, M. A. (2013). Efficient electrosynthesis of highly active $\mathrm{Cu}_{3}(\mathrm{BTC})_{2}-\mathrm{MOF}$ and its catalytic application to chemical reduction. Microporous and Mesoporous Materials, 168, 57-64. doi:10.1016/j.micromeso.2012.09.0 28

Liu, H., Li, Y., Luque R., \& Jiang, H. (2011). A tuneable bifunctional water-compatible heterogeneous catalyst for the selective aqueous hydrogenation of phenols. Advance Synthesis \& Catalysis., 353 (17), 3107-

3113.doi: 10.1002/adsc.201100479.

Mäki-Arvela, P., Rozmyszłowicz, B., Lestari, S., Simakova, O., Eränen, K., Salmi, T., \& Murzi, D. Y. (2011). Catalytic deoxygenation of tall oil fatty acid over palladium supported on mesoporous carbon. Energy and Fuels, 25 (7), 28152825. doi: 10.1021/ef200380w. http://pubs.acs.org/doi/abs/10.1021/ ef200380w.

Opelt, S., Türk, S., Dietzsch, E., Henschel, A., Kaskel S. \& Klemm, E. (2008). Preparation of palladium supported on MOF-5 and its use as hydrogenation catalyst. Catalysis. Communications, 9, 1286-1290. doi:10.1016/j.catcom.2007.11.019

Sabo, M., Henschel, A., Fröde, H., Klemm, E., \& Kaskel, S. (2007). Solution infiltration of palladium into MOF-5: synthesis, physisorption and catalytic properties. Journal of Materials Chemistry, 17, 3827-3832. doi: 10.1039/b706432b

Sotelo-Boyás, R., Trejo-Zárraga, F., \& Hernández-Loyo, F. J. (2012). INTECH, Chapter 8: Hydroconversion of triglycerides into green liquid fuels, pp. 187-212. http://dx.doi.org/10.5772/48710

Yang, Y., Ochoa-Hernandez, C., de la Peňa O'Shea, V.A., Coronado, J.M., \& Serrano, D.P. (2012). $\mathrm{Ni}_{2} \mathrm{P} / \mathrm{SBA}-$ 15 as a hydrodeoxygenation catalyst with enhanced selectivity for the conversion of methyl oleate into $n$ octadecane. ACS Catalysis., 2, 592598. doi: 10.1021/cs200659r .http://pubs.acs.org/doi/abs/10.1021/ cs200659r.

Yang, L., Kinoshita, S., Yamada, T., Kanda, S., Kitagawa, H., Tokunaga, M., Ishimoto, T., Ogura, T., Nagumo, R., Miyamoto, A., and Koyama, M. (2010). A metalorganic framework as an electrocatalyst for ethanol oxidation. Angewandte Chemie International. Edition, 49 (31), 5348-5351. doi: 10.1002/anie. 201000863

Yusuf, N. N. A. N., Kamarudin, S.K., \& Yaakub, Z. (2011). Overview on the current trends in biodiesel production, energy conversion and managemen. Energy Conversion and Management, 52, 2741-2751. http://dx.doi.org/10.1016/j.enconma n.2010.12.004. doi:10.1016/j.enconman.2010.12.00 4

Zhang, F., Shi, J., Jin, Y., Fu, Y., Zhong, Y., \& Zhu, W. (2015). Facile synthesis of MIL-100(Fe) under HFfree conditions and 1st application in the acetalization of aldehydes with diols. Chemical Engineering Journal. 259, 183-190. http://dx.doi.org/10.1016/j.cej.2014. 07.119 